\title{
Martyn Rady
}

\section{The Government of Medieval Buda}

At first sight, the government of medieval Buda resembles arrangements in most Central European cities. The city was founded in the late 1240s in what appears to be an example of Siedlungsverlegung, whereby the privilege of self-government previously granted to Pest was, along with Pest's seal and arms, conferred on the new city set on the Buda Hill. ${ }^{1}$ Buda's origin in the earlier Pest settlement is reflected in its thirteenthcentury name, which alternated between (Novus) Mons Budensis, Civitas Budensis, Castrum Pestiense and (Novus) Mons Pestiensis. ${ }^{2}$ Although it is uncertain whether the city was planted by a consortium of enterprisers (Unternehmerkonsortium), it constituted, at least in part, a typically planned settlement. ${ }^{3}$ Judicial, regulatory and administrative authority was vested in a council or Rat of twelve men, headed by a judge (Richter, iudex) or headman (maior ville, villicus), all of whom were annually elected by the citizen community. Later on, in the middle decades of the fifteenth century, the right of election was placed in the hands of an outer council of one hundred citizens. For most of the Middle Ages, the government of the city lay with an urban elite made up of prosperous German merchants, although these were later obliged to share power with representatives of the city's Hungarian population. The sense of urban solidarity underpinning the city's communal organization was played out in the civic rituals of election and of assembly. It is also celebrated in the form of an extensive Stadtrechtsbuch, composed in the early fifteenth century, which brought together Buda's customs, laws and privileges. ${ }^{4}$

The impression of unexceptionalism is, however, illusory, for Buda was unlike the imperial cities that lay to its west. Buda was small and its population, including its suburbs, can scarcely have numbered more than 15,000 persons. The city was, moreover, dominated by the palace and the institutions of royal government. These subverted the jurisdictional rights belonging to the judge and council, even to the extent of overturning the principle of self-government given in the city's founding charter. Buda's customary law was, moreover, twisted as a consequence of the large number of noblemen living in the city, so that the right of the citizen to alienate his property (and thus to use it as collateral in merchant ventures) was compromised. Although Buda's liberties were regularly extended to other towns and cities in the kingdom, the city's development as a typically Central European 'mother town' was hindered by the intrusion of a royal officer into its affairs. In this respect, the history of medieval Buda's

\footnotetext{
${ }^{1}$ Kubinyi, Anfänge Ofens, p. 70. For Siedlungsverlegung as involving both the physical and legal transfer of the settlement, see Herbert Fischer, Die Siedlungsverlegung im Zeitalter der Stadtbildung (Vienna: Verlag Herold, 1952), p. 15. For the link between Siedlungsverlegung and Wappenverleihung, see Christa Schillinger-Prassl, Die Rechtsquellen der Stadt Leoben (Vienna-Cologne-Weimar: Böhlau, 1997), p. 33.

2 Györffy, Budapest, p. 298.

3 Kubinyi, Anfänge Ofens, pp. 29 and 63; Katalin Szende and András Végh, "Royal Power and Urban Space in Medieval Hungary," in Lords and Towns in Medieval Europe: Maps and Texts, eds Anngret Simms and Howard B. Clarke (Farnham: Ashgate [in press]).

${ }^{4}$ For the Stadtrechtsbuch see: OSt. This supersedes the edition of Andreas Michnay and Paul Lichner, Ofner Stadtrecht von MCCXLIV-MCCCCXXI (Pressburg: Carl Friedrich Wigand, 1845). See also Buda város jogkönyve, 2 vols [The law code of Buda], eds László Blazovich and József Schmidt (Szegedi Középkortörténeti Könyvtár, 17) (Szeged: Szegedi Középkorász Műhely, 2001), which includes a translation of the Stadtrechtsbuch into Hungarian and supporting essays in German.
} 
government may most profitably be conceived from the perspective of a Residenzstadt, wherein the jurisdictional rights of the city and its autonomy were circumscribed by proximity to the institutions of territorial lordship. ${ }^{5}$

\section{Villicus and rector}

The 1244 charter (see Appendix 2) was granted by Béla IV in the aftermath of the destruction of the Pest settlement by the Mongols in 1241-1242.6 The original does not survive, but plainly it carried the king's pendant gold seal. ${ }^{7}$ The privilege commences with an arenga typical of this decade, in which the king declares his wish to augment the number of his subjects. ${ }^{8}$ Explaining that Pest's original charter had been lost at the time of the Mongol invasion, Béla confirmed its contents, most of which were concerned with the city's commercial rights. It included, however, a short provision on the city's government: "They [the citizens] may elect a mayor of the town, whomever they want and once elected they shall present him to us, and he should judge all their secular affairs. If he does not demonstrate to anyone the justice that is due, the headman and not the city shall be brought before us or to someone appointed by us." 9 The same principle of self-government was enunciated in the charter issued by Ladislas IV in 1276. On this occasion, however, reference was no longer made to Pest, but to the castrum of Buda, and Ladislas IV's grant is described as amplifying the terms of the 1244 charter- "We further grant to them [the citizens] that they shall not be forced to accept any judge appointed by us, but they shall have as headman whomever they wish by free election, as was laid down earlier in the text of the privilege of our grandfather [Béla IV], and the headman should annually resign his office into the hands of the

\footnotetext{
${ }^{5}$ For Buda as a Residenzstadt, see András Kubinyi, "Királyi székhely a késő középkori Magyarországon," [Royal seat in late medieval Hungary] in Kubinyi, Tanulmányok, i, pp. 223-227, here 224. Also Katalin Szende, "Városkutatás és rezidencia-kutatás. Európai helyzetkép és magyar eredmények," [Urban history research and Residenzforschung. European overview and Hungarian state of research] Urbs. Magyar Várostörténeti Évkönyv 7 (2012), pp. 11-44, here pp. 27-30; József Laszlovszky and Katalin Szende, "Cities and Towns as Princely Seats: Medieval Visegrád in the Context of Royal Residences and Urban Development in Europe and Hungary," in The Medieval Royal Town at Visegrád: Royal Center, Urban Settlement, Churches (Archaeolingua - Main Series, 32), eds József Laszlovszky, Gergely Buzás and Orsolya Mészáros (Budapest: Archaeolingua, 2014), pp. 9-44. For the impact more generally of the Residenz on urban autonomy, see Frank G. Hirschmann, Die Stadt im Mittelalter (Munich: Oldenbourg, 2009), pp. 35-36.

${ }^{6}$ The charter was clearly awarded to the older Pest settlement and not to the nascent community on the Buda hill. It thus refers to Pest minor (Kreinfeld, Kelenföld) as lying on the 'further' bank of the Danube (Minor Pesth ultra Danubium sita). See Elemér Révhelyi, "Kelenföld (Tabán) helye és neve," [The location and the name of Kelenföld (Tabán)] Tanulmányok Budapest Múltjából 4 (1936), pp. 34-58, here p. 36. The transfer of the population and of their legal rights to Buda must have happened in the late $1240 \mathrm{~s}$. See András Végh, "Buda" in Medium regni, pp. 163-212, here p. 207.

7 The text is given in BTOE, i, pp. 41-43 (no 27); also in EFHU, iii/2, pp. 39-41 (no 34). An English translation is given in Ágnes Ságvári, Budapest: the History of a Capital (Budapest: Corvina, 1973), pp. 78-79. See both the edited text of the original charter and the translation in the appendix of the present volume.

8 On the arengas of charters given to Hungarian cities in the thirteenth century, see András Kubinyi, "A királyi várospolitika tükröződése a magyar királyi oklevelek arengáiban," [Royal urban policy as reflected in the arengas of Hungarian royal charters] in Eszmetörténeti tanulmányok a magyar középkorról [Studies in the intellectual history of medieval Hungary], ed. György Székely (Budapest: Akadémiai, 1984), pp. 275-291.

${ }_{9}^{9}$ EFHU, iii/2, p. 39-41 (no 34). See Appendix 2.
} 
citizens." 10 Although neither charter refers to an elected council, this was clearly in place by no later than $1268 .{ }^{11}$

Despite the terms of the 1244 charter and its confirmation more than thirty years later, it is evident that the right of self-government was soon disregarded by the ruler. Around 1260, the city was represented in litigation by the villicus Peter. ${ }^{12}$ Thereafter, however, the office of elected headman was superseded by a royal appointee, who held the title of rector. The first of these was the Lower Austrian knight, Henry Preussel (Preuchul), who was appointed rector by Béla IV during the course of his war with his son, Stephen (V). Preussel was killed in battle in 1265 and his place briefly taken by one of Stephen's supporters, the Ban Mikod.13 With the restoration of peaceful conditions, we might have expected the office of elected headman to be re-established and there is some possibility that for a time the government of the city was returned to Peter, acting in the capacity of former (quondam) villicus. ${ }^{14}$ In 1268, however, the office of rector was given to the chamberlain (count) of the treasury, Walter. The selection of Walter for this role seems part of a deliberate strategy to impose officers of the royal mint over several of the kingdom's cities - much the same happened in Zagreb, where in 1266 the chamberlain Archynus was imposed as judge. ${ }^{15}$ The policy of combining urban and fiscal functions did not endure beyond the 1280s. ${ }^{16}$ Rectors continued, nevertheless, to be appointed as judges over the city, acting explicitly in the role of the monarch's plenipotentiaries, pro tempore constituti. ${ }^{17}$ It was not, indeed, until the mid-1340s that the city was able to make good the right to appoint its chief magistrate.

The office of rector partly survived because it was useful to a small group of the city's citizens, whose members filled the office over decades, often being replaced by their sons. Outsiders who were drafted in might, like the rector Walter, be murdered by scions of the older established families, or, like Peterman, imposed on the city in 1301 by the Bohemian king, forced after a short time to flee. All in all, we can establish two sets of families who dominated the office of rector. ${ }^{18}$ The first comprised the

\footnotetext{
10 "Ad hec concessimus eisdem, ut non cogantur recipere aliquem judicem per nos datum, sed ex electione sua Iibera assumant in villicum, quem volunt, prout in tenore privilegii avi nostri superius est expressum, qui quidem villicus in anni revolutione villicatum debeat in manus civium resignare" - BTOE, i, pp. 157158 (no 140); EFHU, iii/2, pp. 64-65 (no 55). The 1276 privilege is given in English translation in Ságvári, Budapest, p. 80.

${ }^{11}$ BTOE, i, pp. 100-101 (no 86); EFHU, iii/2, pp. 59-60 (no 50). A list of Buda's judges and councillors for the period 1259 to 1529 is given in Rady, Buda, pp. 169-176.

12 BTOE, i, pp. 70-71 (no 53) and 73-74 (no 57).

${ }^{13}$ Kubinyi, Anfänge Ofens, p. 72; for Mikod, see also Attila Zsoldos, Magyarország világi archontológiája 1000-1301 [Secular archontology of medieval Hungary] (História könyvtár. Kronológiák, adattárak, 11) (Budapest: História - MTA Történettudományi Intézete, 2011), p. 147.

${ }^{14}$ BTOE, i, pp. 71-72 (no 54). See also Erik Fügedi, "Középkori magyar városprivilégiumok," [Medieval Hungarian urban privileges] in idem, Kolduló barátok, polgárok, nemesek. Tanulmányok a magyar középkorról [Mendicants, burghers and nobles. Studies on the history of medieval Hungary] (Budapest: Magvető, 1981), pp. 238-310, here p. 308.

15 Klaus-Detlev Grothusen, Entstehung und Geschichte Zagrebs bis zum Ausgang des 14. Jahrhunderts (Wiesbaden: Harrassowitz, 1967), pp. 279-281.

${ }_{16}$ Possibly the Rector Hench (Heinz), who held office from the late 1270s to 1288, is identifiable with a chamberlain of the same name. See Kubinyi, Anfänge Ofens, p. 73; Zsoldos, Magyarország világi archontológiája, p. 248.

17 Hence, "Nos Carolus de Veteri Buda miles, iudex pro domino rege in Buda" - Monumenta Romana episcopatus Vesprimiensis, i, ed. Vilmos Fraknói (Budapest: [n. p.], 1896), p. 302 (1276); BTOE, i, p. 230231 (no 215) (1287).

18 For this and much of what follows, András Kubinyi, "A budai német patriciátus társadalmi helyzete családi összeköttetései tükrében a 13. századtól a 15. század második feléig," [The social position of the
} 
descendants of the villicus Peter, whose own period in office had been cut short by the imposition of royal rectors. Peter was probably himself the son of the knight Werner, who had in the 1230s built a palace on the left bank of the Danube. We can speculate that Werner and Peter were both active as entrepreneurs in establishing the settlement on the Buda Hill. Peter's son and grandson, Werner and Ladislas respectively, were complicit in Walter's murder in 1276 and they in turn held the office of rector, with only a few short breaks, from 1288 to around 1319. Ladislas, who died without heir, was in 1319 replaced as rector by Johannes, and Johannes was in turn succeeded in 1337 by his son, Nicholas. ${ }^{19}$ The rectors were also connected by marriage and descent to many of the families whose members served on the council. Almost a half of council places were in the 1330s held by relatives of the rectors Johannes and Nicholas. ${ }^{20}$

The institution of rectors also benefited the ruler. The heart of the new city lay to begin with on the north part of the Buda Hill, in the area between the Magdalene church and the Church of Our Lady, which was also the site of the Saturday (later Friday) Market. ${ }^{21}$ Both churches were in operation by the 1250s. Overlooking the Danube were two further stone buildings - the Dominican friary and a royal palace or Kammerhof. The layout of the city walls suggests that these were built prior to or at the same time as the city's fortification and they may indeed be older than the 1240s. The Kammerhof fulfilled a double function. ${ }^{22}$ It was a mint, which we know to have been functioning as early as 1255 , but it was also a royal residence. The combination of mint and royal residence is not unusual - the fourteenth-century Visegrád palace, the so-called Italian Court in Kutná Hora in Bohemia, and the Brussels Prinsenhof also fulfilled both roles. ${ }^{23}$ Plainly, the rectors had some sort of responsibility for the Kammerhof. We have already noted how the rector Walter was a chamberlain of the mint. Peterman was subsequently described as the prefect of Buda and of its citadel and the rector Johannes as the capitaneus of Buda, which suggests a military function, possibly in relation to the palace garrison. ${ }^{24}$ The identification made in 1315 of the title of rector with the conservator domus regiae further indicates that the rectors may have acted in the capacity of castellans, with a particular responsibility for the maintenance of the Kammerhof. ${ }^{25}$

\footnotetext{
German patriciate in Buda in the light of their family ties from the $13^{\text {th }}$ to the second half of the $15^{\text {th }}$ century] in Kubinyi, Tanulmányok, ii, pp. 457-511, here p. 467-473.

${ }^{19}$ For Ladislas, see also Végh, Buda, i, p. 140.

${ }^{20}$ Kubinyi, "A budai német patriciátus," p. 473.

${ }^{21}$ Discussed in further detail above, András Végh's contribution to the present colume deals with this.

${ }^{22}$ The extensive literature on the Kammerhof is reviewed in Végh, Buda, i, pp. 271-272; Károly Magyar, $A$ budai középkori királyi palota épitészeti együttesének változásai (1340-1440) európai kitekintésben, unpublished $\mathrm{PhD}$ dissertation [The history of the architectural ensemble of the medieval palace of Buda (1340-1440) in European context] (Budapest: ELTE, 2008), pp. 13-14. See also Károly Magyar's contribution to the present volume.

23 Peter Spufford, "The Mint Buildings of Medieval Europe," in XIII Congreso Internacional de Numismática, ii, eds Carmen Alfaro et al. (Madrid: Ministerio de Cultura, 2003), pp. 1059-1065, here pp. 1061-1064 (with additional examples); Klára Benešovská, Architecture of the Gothic (Prague: Prague Castle Administration, 2001), p. 244; Gergely Buzás, "Visegrád," in Medium regni, pp. 115-161, here p. 120.

${ }^{24}$ Gusztáv Wenzel, “Budai regeszták," Magyar Történelmi Tár 1 (1855), pp. 69-124, and 4 (1857), pp. 89182, here p. 112; CD, viii/3, pp. 386-387 (no 163).

25 György Györffy, Pest-Buda kialakulása. Budapest története a honfoglalástól az Árpád-kor végi székvárossá alakulásáig [The formation of Pest-Buda. The history of Budapest from the Hungarian conquest to its late Árpádian-period formation as capital] (Budapest, Akadémiai, 1997), p. 194; Végh, Buda, i, pp. 166 and 173.
} 
We do not know when the Kammerhof ceased to function as a palace and mint, but it seems to have been during the reign of Louis I. ${ }^{26}$ It was subsequently known as the antiqua domus regis, the royal mint having shifted in the meantime to a site adjacent to the Church of Our Lady. ${ }^{27}$ Doubtless, its role as a royal residence was superseded by the larger palace at the southern end of the Buda Hill, which was extensively rebuilt during King Louis's reign. As the center of political weight shifted from the north of the Buda Hill, the office of rector was allowed to lapse. Already by the 1330s it had become usual for one of the city's elected councillors to act in the capacity of vice-iudex, discharging some of the duties that otherwise belonged to the rector. ${ }^{28}$ So when in either 1346 or 1347 the rector Nicholas died, the office of elected chief magistrate and headman might be straightforwardly restored, with the vice-iudex taking on the functions of chief magistrate. ${ }^{29}$ Certainly, the surviving council lists do not indicate any great change in membership that might be taken as evidence of a putsch. Moreover, the new judge, Lorand, had served as a councillor for at least a decade. The institution of royallyappointed rectors thus came to an end without any attendant turmoil. Nevertheless, the history of the rectors, which extended for almost seventy years, in apparent defiance of the city's charters, indicates Buda's vulnerability to royal intrusions on its right of selfgovernment.

\section{Institutions of Government}

The city's restored self-government was headed by an elected judge or Richter and a council or Rat of twelve. The judge was consistently described in the Latin documents issued by the city as a iudex and the councillors as iurati (Geschworenen), on account of the oaths of office that they swore on the occasion of their appointment. ${ }^{30}$ Buda also had a Stadtschreiber, or city scribe, appointed by the judge and council, who was in charge of the city's chancellery. ${ }^{31}$ Although the city's archive was destroyed during the Ottoman occupation, its scribal office was evidently large, being divided into several departments, each having its own seal. ${ }^{32}$ Subordinate magistrates took charge of business in the suburbs and also heard commercial disputes. ${ }^{33}$ A Judge of the Money or Geldrichter (iudex pecuniarum) was responsible for hearing litigation involving financial disputes up to the value of forty florins. The Geldrichter was appointed by the judge out of the ranks of the councillors and later acted as the city's deputy judge. ${ }^{34}$ The Geldrichter had a deputy, whose task it was to resolve disputes involving minor debts. ${ }^{35}$

\footnotetext{
${ }^{26}$ András Végh, "A középkori várostól a török erődig," [From the medieval town to the Ottoman fortress] Budapest Régiségei 31 (1997), pp. 295-312, here p. 295.

${ }^{27}$ BTOE, iii/2, p. 8 (no 683) (1416). The Buda Stadtrechtsbuch likewise refers to the alten kamerhoff peyn Iudenn (OSt, p. 46 [Prol., D]). For the subsequent location of the mint, see Lajos Huszár, A budai pénzverés története a középkorban [The history of minting at Buda in the Middle Ages] (Budapest: Akadémiai, 1958), p. 21. See also, Végh, Buda, i, p. 267.

${ }^{28}$ Kubinyi, Budapest, p. 80.

${ }^{29}$ The surviving list of councillors for 1346-1347 gives the names of the judge and of only eleven councillors. Presumably, the judge had upon Rector Nicholas's death been appointed from out of the twelve and had not been replaced.

30 The title of villicus was not restored.

${ }^{31}$ OSt, p. 69. (cap. 28).

32 Kubinyi, Budapest, pp. 167-168.

33 OSt, p. 72. (cap. 33).

${ }^{34}$ See OSt, p. 78. (cap. 49), where the Geldrichter is considered a Stadtrichter. The vacancy left among the twelve by the appointment of the Geldrichter was filled at the discretion of the judge, who had the right to co-opt.OSt, p. 69 and 199 (cap. 29 and 167).

35 OSt, p. 120 (cap. 171).
} 
As was typical in the Middle Ages (and indeed later), no distinction was made between judicial and administrative competences. Nevertheless, in the organization of business coming before it, the council gave priority to its role as a court of law, in which capacity it met as a magistracy on three days in the week. Of the remainder, one day was given over to city business and a further day to discussing matters affecting ecclesiastical institutions. ${ }^{36}$ Besides their judicial duties, the judge and sworn men of the council were in charge of the public works of the city and responsible for composing commercial regulations affecting the quantities of goods that might be put up for sale, for maintaining order in the markets, for regulating the guilds, and for the appointment of watchmen, dung collectors, and so on. The judge and council were also empowered to notarize conveyances and to see that new owners took possession of property within the city with the necessary procedural safeguards. Most contentiously, they were in charge of allocating taxes within the city. They were assisted in this task by an advisory body of twenty-four citizens made up of appointees of the council. ${ }^{37}$ This was intended as a safeguard against malfeasance and had been instructed by King Sigismund in 1403 following disturbances, which appear to have been caused by perceived inequities or irregularities in the collection of taxation. ${ }^{38}$ The council also appointed a dozen or so officers to help with the assessment of taxes from vineyards. ${ }^{39}$

The principal source for the government of Buda is the city's Stadtrechtsbuch, which was composed in stages during the earliest decades of the fifteenth century. 40 Since it contains extracts from royal legislation given in 1405, this year represents the terminus post quem for its text. The inclusion of craft and commercial regulations drawn up by the council in 1421 and reference to a judgment of 1424 suggest that the bulk of the volume was drawn up around this time. The text only survives in later copies, and the stages of its composition are uncertain. Plainly though, a good part of the book was the work of one man, who tells us at one point that he is called Johannes. The text is long, running to 175 pages in the leading edition - 445 chapters in all, in addition to a Prologue. Its purpose is, however, less certain, for it provides no insights into the daily routines of city government. Its account of legal practices is thin and mostly concerned the presentation of plaints. It says nothing about the warrantying of property even though charters issued by the council regularly spelled out that this was an integral and ancient part of the city's customary law (secundum usum et consuetudinem nostre civitatis ab antiquo approbatam). ${ }^{41}$ Other aspects of the city's allegedly customary procedures are also missing, as for instance the manner of responding to a summons. ${ }^{42}$ The main part of the text includes no references to judgments of the council and thus to the 'living law' of the city. ${ }^{43}$ Johannes and his continuators knew something, however, of the city's charters and they quote passages

\footnotetext{
36 OSt, pp. 119-120 (cap. 168).

37 OSt, p. 63. (cap. 12).

38 BTOE, iii/1, pp. 181-182 (no 370); OSt, p. 63 (cap. 15).

${ }^{39}$ OSt, p. 140 . (cap. 236/b).

40 For the manuscripts of the Stadtrechtsbuch, see Katalin Gönczi, Ungarisches Stadtrecht aus europäischer Sicht. Die Stadtrechtsentwicklung im spätmittelalterlichen Ungarn am Beispiel Ofen (Frankfurt am Main: Klostermann, 1997), pp. 82-83.

41 BTOE, iii/1, pp. 8, 10, 12-13, 20, 22, 23 (nos 19, 23, 28, 49, 52, 54, etc.).

42 András Kubinyi, "A budai jogkönyvról. Ismertetés Mollay Károly monográfiájáról," [On the Law Code of Buda. Review of Károly Mollay’s monograph] in Kubinyi, Tanulmányok, i, pp. 297-298, here p. 298.

43 The contrast with the earlier Vienna Stadtrechtsbuch is in these respects striking. See Heinrich Maria Schuster, Das Wiener Stadtrechts- oder Weichbildbuch (Vienna: Manz, 1873), pp. 37-38.
} 
from them, including texts taken from documents that have since been lost. ${ }^{44} \mathrm{~A}$ large part of the text is dedicated to the regulation of the crafts and to civic rituals, which are often described in lavish detail.

The principal event in Buda's civic ceremony was the election of the judge, council and Stadtschreiber. This was performed annually on St George's Day (April 24) in the main square between the City Hall and the Church of Our Lady. The outgoing judge solemnly laid down his staff of office and the citizens deliberated on his successor in the presence of the whole community, eventually arriving at a unanimous decision. ${ }^{45} \mathrm{~A}$ similar process attended the appointment of the councillors and city scribe, although Johannes's description of their election is slender. Judge, councillors and Stadtschreiber delivered their oaths of office, which the Stadtrechtsbuch repeats in full. ${ }^{46}$ Thereafter, Buda's principal seal was brought from the City Hall, taken out of its locked box, and shown to the crowd. ${ }^{47}$ The judge was then formally presented to the king or, in his absence, to the burgrave of the palace, in accordance with the terms of the 1244 privilege. ${ }^{48}$ On the Friday following the election, the judge and councillors toured the city, and householders were expected to greet them appropriately. ${ }^{49}$ The Stadtrechtsbuch also describes in detail the festivities on the occasion of a royal coronation or upon the king's entry to the city. ${ }^{50}$

The account given in the Stadtrechtsbuch of elections to city offices presents authority as being vested in the community, all sections of which, rich and poor, were participants in its ritual. In fact, the right of election belonged to the small section of the population who owned property within it, thus constituting "the commons of the city, well possessed and landed, sensible people" (Der stat gemain wol gessessen vnd geerbt, Vernunftige leüt). ${ }^{51}$ All others were simply spectators. Plainly, however, elections did not always proceed in the calm and sober atmosphere described in the Stadtrechtsbuch. We know, therefore, that in 1402 there were irregularities in the election of the judge and council, which resulted in an 'illegal' government that lasted for more than a year. ${ }^{52}$ The names of the supposed conspirators - Andrew the Butcher and Lawrence the Furrier - suggest that the coup, if such it was, may have been engineered by guildsmen. Possibly, their actions were motivated by contemporary concerns over taxation or were aimed at breaking the power of the merchant families who dominated city government. Although Andrew and Lawrence were subsequently forbidden by Sigismund from holding office in the city, surviving council lists indicate that members of the wealthier craft guilds were from this point onwards more likely to win places in Buda's government. In 1420, the office of judge was held by a guildsman (Johannes Rasor). ${ }^{53}$

\footnotetext{
${ }^{44}$ OSt. p. 86 (cap. 65). Discussed by András Kubinyi, “Die Fleischerzunft zu Ofen im Mittelater," in $A$ budai mészárosok középkori céhkönyve és kiváltságlevelei - Zunftbuch und Privilegien der Fleischer zu Ofen aus dem Mittelalter. (Források Budapest közép- és kora újkori történetéhez, 1 / Quellen zur Budapester Geschichte im Mittelalter und in der frühen Neuzeit, 1), ed. István Kenyeres (Budapest: BFL - BTM, 2008), pp. 87-138, here pp. 89-90.

45 OSt, pp. 67, 70-71 and 83 (cap. 24, 31, 32, 58 and 59).

46 OSt, pp. 75-76. (cap. 42-44).

47 OSt, p. 84. (cap. 62).

48 OSt, p. 67 and 71 (cap. 24 and 32).

49 OSt, p. 82 (cap. 57 ).

50 OSt, pp. 61-62 (cap. 6 and 7).

51 OSt, p. 67 (cap. 24).

52 BTOE, iii/1, pp. 181-182 and 188-189 (nos 370 and 383); see also Kubinyi, Budapest, pp. 68-69.

53 BTOE, iii/2, pp. 47-49 (no 767).
} 
The Stadtrechtsbuch also noted that when weighty business needed discussion sworn representatives of the guilds should attend the City Hall. ${ }^{54}$

For the first two centuries of its history, Buda's government was dominated by Germans - a circumstance which prevailed in most of Hungary's cities. ${ }^{55}$ Germans held the high office of judge and the majority of places on the council. The Stadtrechtsbuch declared that the judge should be a German of pure descent (derr selbig richterr von deutscher artt sey von allem geschlächt) and that ten of the city councillors should be German, the remaining two Hungarian. ${ }^{56}$ Lists of councillors included in letters issued by the city indicate that the bottom two or three places were generally held by Hungarians. Buda was a bilingual city and the oaths delivered by the incoming judge and councillors were delivered in both German and Hungarian. ${ }^{57}$ Nevertheless, it was also a divided city, with separate guilds for Germans and Hungarians, different markets and market days, competing churches, and little evidence of inter-marriage between the two communities. ${ }^{58}$ The Germans' mastery of the city reflected their commercial predominance and their superiority in terms of wealth, which sustained their control of the organs of government. During the late fourteenth and early fifteenth centuries, however, the fortunes of Buda's German elite experienced a downturn. Many of the leading families either died out or, having made money, left the city. They were partly replaced by poorer elements, who lacked the wealth and trading connections of their predecessors, and by guildsmen. By contrast, the Hungarian population of the city prospered, often as a consequence of their links to the royal court and palace. ${ }^{59}$ The number of Hungarians living in Buda was swollen by noblemen and churchmen, who often bought houses in the city, and by the clerks and litterati who worked in the royal administration after it moved to Buda in the first decade of the fifteenth century. At its height, the royal court and central offices of the kingdom had more than a thousand staff and we must imagine that most of these were resident in the city. ${ }^{60}$ During the period of the king's residence in the palace and when the courts were in session, the number of Hungarians in the city was further swollen by the influx of petitioners, litigants and lawyers. These thronged the inns, where a part of a part of the kingdom's judicial business was consequently undertaken. 61

German hegemony was manifested in the confraternity known as the Corpus Christi fellowship, attached to one of the altars in the Church of Our Lady, which counted at this time as the principal German church in the city. The confraternity was wealthy and its members well-connected. Later evidence shows that it held assets in

\footnotetext{
${ }^{54}$ OSt, p. 72 (cap. 34).

${ }^{55}$ See more generally on this subject, András Kubinyi, "Die Zusammensetzung des städtischen Rates im mittelalterlichen Königreich Ungarn," Südostdeutsches Archiv 34-35 (1991-1992), pp. 23-42 (also published in idem, König und Volk im spätmittelalterlichen Ungarn: Städteentwicklung, Alltagsleben und Regierung im mittelalterlichen Königreich Ungarn [Herne: Tibor Schäfer, 1998], pp. 103-23).

56 OSt, pp. 67-69 (cap. 24 and 27).

57 On language use in medieval Hungarian cities, see Katalin Szende, "Integration through Language: the Multilingual Character of Late Medieval Towns," in Segregation - Integration - Assimilation. Religious and Ethnic Groups in the Medieval Towns of Central and Eastern Europe (Historical Urban Studies), eds Derek Keene, Balázs Nagy and Katalin Szende (Farnham: Ashgate, 2009), pp. 205-233.

${ }^{58}$ Kubinyi, "A budai német patriciátus," p. 508.

59 András Végh, "Buda: the Multi-Ethnic Capital of Medieval Hungary," in Segregation - Integration Assimilation, pp. 89-99, here p. 92.

${ }^{60}$ Kubinyi, "Királyi székhely," p. 225.

${ }^{61}$ Imre Hajnik, A magyar birósági szervezet és perjog az Árpád- és a vegyes-házi királyok alatt [The judicial system and procedural law in Hungary during the Árpádian period and the reigns of kings of different houses] (Budapest: MTA, 1899), pp. 229-230.
} 
Nuremberg alone estimated at over 2000 gulden. In 1526, on the eve of Mohács, it deposited 5000 gulden for safe-keeping in Nuremberg. ${ }^{62}$ The confraternity and the ecclesiastical arrangement which made the Hungarian Church of Mary Magdalene subordinate to Our Lady's became the focus of resentment. In July 1436, visitors from Pressburg reported that a certain George Litteratus "has caused great unhappiness amongst the priesthood and particularly to the priest of Our Blessed Lady's. He would like Our Lady's to be the chapel and filial Church of Mary Magdalene. Along with his Hungarian supporters he wants to confiscate the luxuries which people have left to Our Lady's and especially those most valuable treasures which have been given to the Corpus Christi Brotherhood. He is plotting all sorts of incredible things." 63 The Germans were not slow to act. To pre-empt the opposition, they secured in 1437 the election as judge of a wealthy Hungarian, who by marriage and commerce had aligned himself with the city's Germans. ${ }^{64}$ When this measure proved insufficient, some leading Germans kidnapped in May 1439 one of the city's Hungarian spokesmen and had him murdered. Upon discovery of the crime, rioting broke out, with German shops and homes destroyed and their occupants killed. 65

The disorder could scarcely have lasted more than a few hours, but in its wake a far-reaching reform of Buda's institutions was undertaken. ${ }^{66}$ Henceforth, parity would be observed in respect of appointments to the council, with Hungarians and Germans having six representatives each. The office of judge would alternate annually between the two national groups. The right of election was, however, now circumscribed. Plainly, the interests of the Hungarian and German leadership coincided - neither had any interest in extending political power down the social scale, particularly to the poorer elements in the city, who seem to have been mainly responsible for the recent violence ${ }^{67}$ Accordingly, the right of election was taken out the hands of the stat gemain of the Stadtrechtsbuch and entrusted to a body of one hundred citizens, made up equally of Germans and Hungarians, who were co-opted by the outgoing judge and council. ${ }^{68}$ To their number were added representatives of the guilds. The committee of twenty-four, which had supervision of tax collection, was also split equally between Hungarians and Germans. The arrangements laid down in 1439 endured until the expulsion and massacre of the Germans by the Ottomans fifty years later, and were in the early eighteenth century restored following the city's recapture. ${ }^{69}$ Such was their reputation for the maintenance of stability that they were at the royal instruction

62 Martyn C. Rady, "Church, Nationality and Revolt in Late Medieval Buda," in The Church in Pre-Reformation Society: Essays in Honour of F. R. H. Du Boulay, eds Caroline M. Barron and Christopher Harper-Bill (Woodbridge: Boydell, 1985), pp. 189-198, here p. 194.

63 Kubinyi, Budapest, p. 71.

${ }^{64}$ Kubinyi, "A budai német patriciátus," p. 493.

65 András Kubinyi, "Népmozgalmak Budapesten a feudalizmus korában," [Popular movements in Budapest in the feudal period] Tanulmányok Budapest Múltjából14 (1961), pp. 7-15, here pp. 9-10.

66 The new arrangements are given in Elek Jakab, Oklevéltár Kolozsvár története elsó kötetéhez, i (Buda: A Magy. Kir. Egyetemi Könyvnyomdában, 1870) [Documentary Collection for the history of Cluj], pp. 280285.

67 Kubinyi, “Népmozgalmak Budapesten,” p. 9.

68 The institution of an Outer Council plainly derived from practices followed elsewhere. See Eberhard Isenmann, Die deutsche Stadt im Mittelalter 1150-1550 (2 ${ }^{\text {nd }}$ ed. Vienna-Cologne-Weimar: Böhlau, 2012), pp. 269 and 377.

69 István Nagy, "A választó polgárság testülete Budán a XVIII. században," [The body of burgher electors in $18^{\text {th }}$-century Buda] Tanulmányok Budapest Múltjából 13 (1959), pp. 139-166. See also, István Kenyeres, "Buda és Pest útja az 1703. évi kiváltságlevélig," [Buda and Pest until its letter of privilege in 1703] Urbs. Magyar Várostörténeti Évkönyv1 (2006), pp. 159-201. 
extended in 1458 to the Transylvanian city of Cluj. ${ }^{70}$ In respect of Buda's ecclesiastical organization, the Hungarian Church of Mary Magdalene, together with the Church of St Peter Protomartyr, were given a status equal to Our Lady's, within newly defined parish boundaries. ${ }^{71}$ We should, however, note that the priest of Our Lady's, who should by the terms of the 1244 charter and according to the Stadtrechtsbuch have been elected by the citizens, was from the mid-fifteenth century onwards usually a royal appointee and often of Hungarian origin. ${ }^{72}$

\section{Urban Law, Noble Law and the Tavernicus}

The central, walled part of the city was extensively settled in the fifteenth century by noblemen. The most southerly part of the city, which lay next to the royal palace, included members of some of the greatest baronial families (Somi, Perényi, Bánfi; later the Szapolyai, Kubinyi etc). ${ }^{73}$ The square nearest to the palace (Szent György) was occupied by a mixture of wealthy German merchants and prominent noblemen, and over the course of the fifteenth century these squeezed out the citizens. ${ }^{74}$ Even in other areas of the city, where craftsmen and merchants predominated, we may note the presence of noble homes, including large mansions. ${ }^{75}$ According both to the 1244 privilege and the Stadtrechtsbuch, all those with property in the city were expected to contribute to taxation. It seems, however, that many nobles shirked this responsibility (although some plainly paid). ${ }^{76}$ In 1492 , it was laid down by the diet that noblemen living in Buda were exempt from city taxes and the text of the law implied that this was their customary right, which the magistracy had trespassed upon. ${ }^{77}$ Noblemen also regularly conveyed properties within the city or launched legal actions over them using the agency of ecclesiastical chapters rather than the city council.78

The large noble presence within the city affected Buda's laws and customs, which became increasingly influenced by the legal practices observed by the nobility. The city's charters mimicked those published for the nobility, including in their texts warranty clauses, the per eum and renunciatio formulas (which conveyed the property on the new owner's heirs and voided all the vendor's rights), and the promise to reissue upon presentation a patent recording a property transaction in the form of a privilege. The customary law of the nobility influenced not only the form of the city's charters but also Buda's substantive and procedural law. The privilege of 1244 presumed that citizens would leave properties to their heirs. It was only, therefore, when a citizen died without a successor that he might freely dispose of his goods. The Stadtrechtsbuch

\footnotetext{
70 Mária Lupescu-Makó, "Der Ausgleich von Klausenburg 1458," in Klausenburg. Wege einer Stadt und ihrer Menschen in Europa, eds Ulrich Burger and Rudolf Gräf (Cluj: Presa Univ. Clujeană, 2007), pp. 3950; Ágnes Flóra, The Matter of Honour: The Leading Urban Elites in Sixteenth Century Cluj and Sibiu, unpublished PhD dissertation (Budapest: CEU, 2014), pp. 46-48 and 69-71.

${ }^{71}$ Végh, "Buda: the Multi-Ethnic," p. 92; idem, Buda város, i, pp. 123-136.

72 Kubinyi, Budapest, pp. 154-155; András Kubinyi, "Polgári értelmiség és hivatalnokréteg Budán és Pesten a Hunyadi- és a Jagelló-korban," [Burgher intellectuals and bureaucrats in Buda and Pest in the Hunyadi and the Jagiellonian Periods] in Kubinyi, Tanulmányok, ii, pp. 598-619, here p. 609.

73 Végh, Buda, i, pp. 149 and 155.

${ }^{74}$ Végh, Buda, i, p. 171.

75 Végh, Buda, i, p. 209, 223 and 246.

76 Végh, Buda, i, p. 315; Kubinyi, Budapest, p. 153.

77 DRMH, iv, pp. 44-47 (1492:105).

78 BTOE, iii/1, pp. 162-163 (no 329); BTOE, iii/2, pp. 70-71, 73 and 98-99 (nos 815, 821 and 869); Végh, Buda, ii, nos 179, 235, 273, 277, 301, 322, 326 and 366. Cf. OSt, p. 129. (cap. 201) - "Alle kauff schullen geschen mit der stadt prieff".
} 
repeated this provision. ${ }^{79}$ From the fourteenth century onwards, however, the right of heirs to succeed to inherited property was converted in the city to a concurrent right of ownership. Thus, in order to alienate landed estate, the owner had to obtain the consent of his successors and have this formally recorded in the deed of sale or pledge. ${ }^{80}$ In imitation of the noble custom of aviticitas (entailment), the property of citizens was later described as hereditates avitae et paternae. As among the nobility, the main exception to this rule was property that the owner had himself acquired by purchase rather than by inheritance, which remained freely disposable. ${ }^{81}$

The application of noble rules of inheritance to property within the city proved a constraint to mercantile endeavor, as a consequence of which bankruptcy law tended to overlook the rights of successors in favor of commercial creditors. ${ }^{82}$ Nevertheless, the need to obtain the agreement of heirs and kinsmen prior to a sale or pledge was plainly irksome and imposed an unwelcome constraint on alienation. In order to obviate this restriction, citizens sometimes included in deeds of alienation the so-called assumptio clause, borrowed from noble customary practice, which conveyed a fictive consent and imposed penalties on kinsmen should they later contest an alienation. ${ }^{83}$ Nevertheless, the city's laws in respect of property were not completely eroded by noble intrusions. The period of praescriptio, after which a possessor's rights became uncontested (save in cases of malae fidei) remained at a year, thus contributing to the security of ownership, while the rights of daughters to inherit from the paternal estate were generally acknowledged. 84

The attenuation of the city's jurisdictional rights is particularly visible in respect of its appellate authority. From the middle of the thirteenth century, and increasingly thereafter, the liberties given to Buda in the 1244 privilege were conveyed by the ruler on other cities of Hungary, in which respect Buda functioned very much in the manner of a Vorbildstadt. ${ }^{85}$ Even where they were not so expressly granted, it is evident that cities might unilaterally adopt as their own the rights given in the 1244 charter. ${ }^{86}$ Out of the system of charter bestowal the practice developed of cities referring legal actions for adjudication to the place or 'mother city' from which they derived their liberties. The royal law of 1405, known as the Decretum Minus, which was published following an assembly of delegates of the kingdom's cities and towns, sanctioned this practice by permitting litigants "to appeal any judgment passed by their judges and citizens [...] to the judges of that city by whose laws such a city or free town lives." 87

\footnotetext{
${ }^{79}$ OSt, p. 128. (cap. 200).

80 Wenzel, "Budai regeszták," pp. 126-128; BTOE, iii/1, pp. 6-7, 12-13, 22, 23, 300 and 344 (nos 17, 28, 52, 54, 579 and 663); BTOE, iii/2, pp. 96-97, 179-180 and 296 (nos 865, 1021, 1183, etc).

81 Rudolf Schmidt, Statut grada Iloka iz godine 1525 (Zagreb: Nadbiskupska tiskara, 1938), pp. 35 and 65. For the more general subversion of urban law by the noble law of the countryside, see Martyn Rady, Customary Law in Hungary: Courts, Texts and the Tripartitum (Oxford: Oxford University Press, 2015), p. 156.

82 Schmidt, Statut, p. 69.

83 BTOE, ii/1, pp. 9798 (no 197) (1395); MNL OL DL 39213 (1494). The operation of the assumptio is explained in Martyn Rady, "Warranty and Surety in Medieval Hungarian Land Law," Journal of Legal History 23 (2002), pp. 23-36, here pp. 29-34.

${ }^{84}$ Blazovich and Schmidt, Buda város, i, pp. 208-213.

85 Fügedi, "Városprivilégiumok," pp. 290-291. See also Katalin Szende, "Power and Inditity. Royal Privileges to the Towns of Medieval Hungary in the Thirteenth Century," in Urban Liberties and Civic Participation from the Middle Ages to Modern Times, eds Michel Pauly and Alexander Lee (Trier: Porta Alba, 2015), 27-67. For Buda as a Vorbildstadt, see Gönczi, Ungarisches Stadtrecht, p. 75.

86 AO, vii, pp. 402-406 (no 225).

87 DRMH, ii, p. 36.
} 
From an early stage, however, the development of mother-city jurisdiction came into collision with the rights pertaining to the Tavernicus or Magister Tavernicorum. The Tavernicus was a royal officer, who was originally in charge of a servile group of provisioners responsible for stocking the stores on which the king's itinerant court relied. ${ }^{88}$ By the thirteenth century, the Tavernicus had overall responsibility for the kingdom's mints and freedom from the intrusion of the Tavernicus's bailiff and moneyers is listed in the 1244 privilege as one of Pest's liberties. The connection between the kingdom's cities and the minting organization resulted in the Tavernicus acquiring some responsibility for urban affairs. Privileges given to cities in the thirteenth and fourteenth centuries thus occasionally referred to the Tavernicus as the authority to whom appeals from the judgments of the council and petitions for the impeachment of city officers should be addressed. ${ }^{89}$ During the late fourteenth century, the court of the Tavernicus frequently met with assessors drawn from the council of one or more cities of the kingdom. ${ }^{90}$ It was the function of the assessors to assist the Tavernicus in determining what the relevant urban law was. As one Tavernicus explained in 1434, when directing the citizens of Pressburg to attend his court: "On account of the ambiguity and difficult nature of the case, we are unwilling to proceed and pass judgment without your circumspect selves being in attendance."91

Besides the relevant mother city, the Decretum Minus of 1405 listed the Tavernicus's court as an alternative forum to which urban appeals might be brought. Seemingly, therefore, two separate appeal structures were in operation. In practice, however, the mother-city court and the Tavernicus's court combined. The merger of the two institutions took several decades to become complete and in its earliest stages was marked by haphazard arrangements. The Stadtrechtsbuch thus noted that "when the Tavernicus (Tarnagkmaister) wishes to judge matters, he shall summon and call the judge and sworn citizens of the city. And should there be in the city the judge and citizens of other cities he should also call them." ${ }^{22}$ Almost certainly it is this informality of arrangements which explains why on some occasions we will find the Tavernicus judging in the company of just one city's magistracy and on others with representatives drawn from a number of places. ${ }^{93}$ Nevertheless, by the 1440 s the cities whose councillors attended the Tavernicus's court had settled at seven (later eight) - Buda, Košice, Pressburg, Trnava, Prešov, Bardejov and Sopron (and subsequently Pest). All of these, with only one exception, had received Buda's privileges and thus belonged to its jurisdictional orbit as filial cities. ${ }^{94}$ During the second half of the fifteenth century, the seven cities that belonged to the court of the Tavernicus framed their own code of law, the Laws and Customs of the Seven Cities, which was closely modeled on Buda's own customary arrangements. This included such institutions as an Outer Council of a hundred citizens, co-opted by the outgoing council, and a committee of twenty-four citizens to oversee taxation. ${ }^{95}$ The primacy of Buda was further registered in the court's

\footnotetext{
88 István Petrovics, “Tárnokmester," [Tavernicus] in Korai magyar történeti lexikon (9-14. század) [Early Hungarian historical lexicon, $9^{\text {th }}-14^{\text {th }}$ centuries], ed. Gyula Kristó (Budapest: Akadémiai, 1994), p. 662.

${ }^{89}$ Fügedi, "Városprivilégiumok," p. 287.

90 ZsO, i, p. 127 (no 1017); MNL OL DL 71362 and 6998.

91 Imre Szentpétery, "A tárnoki itélőszék kialakulása," [The formation of the court of law of the tavernicus] Századok [Supplementum] 68 (1934), pp. 510-590, here p. 565.

92 OSt, p. 64 (cap. 16).

$93 \mathrm{ZsO}$, ii/1, p. 387 (no 3270); ZsO, ii/2, pp. 183-184 (no 6423) and ZsO, viii, p. 100 (no 254).

94 The exception was Trnava - unsurprisingly since its charter predated the foundation of Buda.

95 The text of the Laws and Customs is reproduced in a garbled form in M. G. Kovachich, Codex Authenticus Iuris Tavernicalis (Buda: Typys Regiae Universitatis Pestanae, 1803). The Latin text is edited
} 
location in the city (and not in the palace) and in the right attaching to the city council to take charge of the court's protocols between sessions. ${ }^{96}$

The development of the court of the Tavernicus into the Buda mother-city court, the law of which closely followed Buda's own, was never complete. As a consequence, the Buda mother-city court did not progress into a Schöffenstuhl in a manner analogous to the privileged families of cities further west. ${ }^{97}$ First, it remained under the presidency of a royal officer, the Tavernicus, who was drawn from the ranks of upper nobility. Secondly, although citizens were present as assessors in the court, noblemen might also be in attendance, thus vitiating the cities' rights to administer their own law. ${ }^{98}$ Moreover, since the Tavernicus's court constituted a royal court, it was possible to appeal actions further and have them taken up into the structure of noble adjudication headed by royal judges and administered by protonotaries trained in the customary law of the nobility. It was only in the 1490s that attempts were undertaken to ensure that, when the suits of citizens were considered, the law followed in the principal royal appeal court should reflect urban customs. Even so, the royal enumeration of the content of the cities' customary law was slender, amounting to only seven articles. ${ }^{99}$ Presumably, in all other regards the noble laws and customs of the kingdom were held to apply. ${ }^{100}$

\section{Conclusion}

In 1847, József Eötvös described Hungary's medieval cities as "alien, representing a separate element outside the collective nation. They stood like German islands in the midst of a Hungarian sea. They had their own foreign language and customs, and, as the Buda Stadtrecht confirms, their foreign laws as well." ${ }^{101}$ Eötvös's stark characterization was an underlying assumption in much historical writing in the nineteenth and twentieth centuries. ${ }^{102}$ Study of Buda's government and of the manner in which it exercised its jurisdiction must qualify this approach. The city's institutions of self-rule were from the very first disturbed by the imposition of a royally-appointed rector in place of an elected headman and judge. Buda's development as a Schöffenstuhl was likewise impeded by the city's subordination to a royal official, the Tavernicus. The Hungarian presence in the city, which was augmented by the proximity of the palace,

by Schmidt, Statut, a German version is given in Štefánia Mertanová, Ius tavernicale: štúdie o procese formovania práva taverníckych miest $v$ etapách vývoja taverniíckeho súdu v Uhorsku (15.-17. stor.) [Studies in the legal development of the tavernical towns in the period of the development of the tavernical court, $15^{\text {th }}-17^{\text {th }}$ century] (Bratislava: Veda and Vydavatel'stvo Slovenskej akadémie vied, 1985), pp. 155-215.

96 Ibolya Felhő, "Buda elsősége a tárnoki városok között," [The primacy of Buda among the towns of the Tavernicus] Tanulmányok Budapest Múltjából 19 (1972), pp. 153-178, here pp. 156-157. The court of the Tavernicus might thus be held, as in 1496, in the home of one of Buda's citizens. See Béla Iványi, Eperjes szabad királyi város levéltára, i [The archive of the free royal town of Prešov] (Szeged: Szegedi Városi Ny., 1931), p. 68.

97 Discussed in Isenmann, Die deutsche Stadt, pp. 193-195.

98 Martinus Georgius Kovachich, Formulae solennes styli in cancellaria... (Pest: Typis Matthiae Trattner, 1799), p. 300.

${ }^{99}$ Kovachich, Codex Authenticus, pp. 45-53.

100 On the more general relationship of Stadtrecht to Landrecht, see Gönczi, Ungarisches Stadtrecht, pp. 213-229.

101 József Eötvös, Magyarország 1514-ben [Hungary in 1514] (Pest: Hartleben, 1847), Ch. 1.

102 Discussed by Katalin Gönczi, $A$ városi jog és feljegyezései a középkori Magyarországon [The urban law and its codifications in medieval Hungary] (Acta Juridica et Politica Fasc. liv, 7) (Szeged: JATE ÁJK, 1998), p. 4. See also, Szende, "Power and Identity,". 
forced the remodeling of its government after 1439 to accommodate the city's growing Hungarian population, while Buda's laws and customs were also influenced by aspects of the larger noble law at work in the kingdom as a whole. Buda was thus never free to develop the autonomy and legal and jurisdictional independence which were the characteristics of urban government elsewhere in Central Europe. ${ }^{103}$ As it was, the urban estate was weak in Hungary. In the case of Buda, this situation was compounded by the city's function as a royal Residenzstadt, which shaped its offices, customary law and the composition of its government. In this respect, Buda's development as a capital took place at the expense of its liberties.

103 Isenmann, Die deutsche Stadt, p. 207. 